UDC 669.712; 531.3

\title{
STUDY OF CONDITIONS OF TRANSITION OF SILICON INTO ALUMINATE SOLUTION DURING LEACHING OF RAW ALUNITE AND ITS REMOVAL FROM THIS SOLUTION
}

\author{
G.I.Alyshanly \\ M.Nagiyev Institute of Catalysis and Inorganic Chemistry, NAS of Azerbaijan \\ alishanova91@mail.ru
}

\begin{abstract}
When extracting aluminum from the alunite ore of the Zaglik deposit by leaching, silicon, which is part of the alunite, passes into solution in the form of a silicate ion in a small amount. Silicon in solution not only degrades the quality of the produced alumina but also contributes to the clogging of pipes and equipment during its production. In this work, we investigated the dynamics of the distribution of silicon in the liquid phase upon leaching of raw alunite at room temperature and heating in an alkaline solution. A method of extracting silicon from an aluminate solution is proposed to obtain high-quality aluminum hydroxide. Desilication was carried out by recirculating the parent solution. The silicon dioxide sorption ability from the solution of the material, which was obtained as a result of acid activation of alunite mud, was investigated. It was found that alunite mud activated with sulfuric acid, in comparison with non-activated mud, has the ability to separate the silicate ion from the aluminate solution with a higher percentage of yield.
\end{abstract}

Keywords: alunite, desilication, alkali, hydrocalumite, Friedel's salt.

doi.org/10.32737/0005-2531-2021-4-71-76

\section{Introduction}

Alunite is the main raw material for the production of alumina $\left(\mathrm{Al}_{2} \mathrm{O}_{3}\right)$. The main impurities in alunite ore are iron, titanium and silicon. Silicon is distributed in the Zaglik alunite ore in the form of quartz (amorphous and crystalline $\mathrm{SiO}_{2}$ ) and kaolinite (dickite $\mathrm{Al}_{2} \mathrm{O}_{3} \cdot \mathrm{SiO}_{2} \cdot 2 \mathrm{H}_{2} \mathrm{O}$ ) [1]. Crystalline quartz does not dissolve in an alkaline solution [2]. It can dissolve in alkali at high concentrations and temperatures. Therefore, the presence of silicon in the solution is associated with the dissolution of the mineral kaolinite. Solubility of kaolinite in alkali occurs at $50-80^{\circ} \mathrm{C}$, and dissolution of quartz at $150-180^{\circ} \mathrm{C}$ [3].

$\mathrm{Al}_{2} \mathrm{O}_{3} \cdot \mathrm{SiO}_{2} \cdot 2 \mathrm{H}_{2} \mathrm{O}+6 \mathrm{NaOH}=2 \mathrm{Na}_{2} \mathrm{SiO}_{3}+2 \mathrm{NaAlO}_{2}+$ $+5 \mathrm{H}_{2} \mathrm{O}$

$\mathrm{SiO}_{2}+2 \mathrm{NaOH}=2 \mathrm{Na}_{2} \mathrm{SiO}_{3}+2 \mathrm{H}_{2} \mathrm{O}$

Sodium silicate, which has passed into solution, reacts with sodium aluminate by the following reaction:

$1.7 \mathrm{Na}_{2} \mathrm{SiO}_{3}+2 \mathrm{NaAlO}_{2}+3.4 \mathrm{H}_{2} \mathrm{O}=$ $\mathrm{Na}_{2} \mathrm{O} \cdot \mathrm{Al}_{2} \mathrm{O}_{3} \cdot 1.7 \mathrm{SiO}_{2} \cdot 1.7 \mathrm{H}_{2} \mathrm{O}+3.4 \mathrm{NaOH}$

The obtained sodium hydroaluminosilicate precipitates in the solution and passes into the mud. The concentration of $\mathrm{SiO}_{2}$ in aluminate solutions obtained by processing alunite can vary within $0.2-0.3 \mathrm{~g} / 1$ [4].
There are two methods for removing silicates from solutions $[5,6]$. The first method consists in the precipitation of sodium aluminosilicate with increasing the temperature of the solution in an autoclave $\left(140-200^{\circ} \mathrm{C}\right)$. This leads to a decrease in the concentration of silicate in the solution, but it does not allow obtainning high-quality aluminum hydroxide $\left(\mathrm{Al}(\mathrm{OH})_{3}\right)$, since the formation of a precipitate of aluminosilicate hydrosodium $\left(\mathrm{Na}_{2} \mathrm{O} \cdot \mathrm{Al}_{2} \mathrm{O}_{3} \cdot \mathrm{nSiO}{ }_{2} \cdot \mathrm{mH}_{2} \mathrm{O}\right)$ leads to the accumulation of insoluble aluminum oxide and not consumed alkali. The composition of the sediment varies depending on the concentration of the solution and on the conditions of the process. According to the second method, the deposition of silicon from the aluminate solution is carried out by adding precipitants such as calcium oxide or calcium hydroxide [7, 8]. These reagents are in solution with $\mathrm{Al}(\mathrm{OH})_{4^{-}}$ and $\mathrm{SiO}_{2}(\mathrm{OH})_{2}$-ions to form hydrogarnets.

Although the $4 \mathrm{CaO} \cdot \mathrm{Al}_{2} \mathrm{O}_{3} \cdot \mathrm{CO}_{2} \cdot 11 \mathrm{H}_{2} \mathrm{O}$ precipitate formed when using $\mathrm{Ca}(\mathrm{OH})_{2}$ has a high desiliconizing ability, it is not considered an effective silicon (IV) precipitator, since this compound also precipitates $\mathrm{Al}^{3+}$ from an aluminate solution [9]. The addition of $\mathrm{CaO}$ and $\mathrm{Ca}(\mathrm{OH})_{2}$ to the solutions under study is not acceptable, since alunite solutions contain a suf- 
ficient amount of sulfate ions, which forms $\mathrm{CaSO}_{4} \cdot 2 \mathrm{H}_{2} \mathrm{O}$.

Recently, Yuan and Zhang found that tricalcium hydroaluminate $\left(3 \mathrm{CaO} \cdot \mathrm{Al}_{2} \mathrm{O}_{3} \cdot 6 \mathrm{H}_{2} \mathrm{O}\right)$ can completely remove silicate ions from an aluminate solution with a high caustic modulus $\left(\mathrm{K}_{\alpha}\right)$ [10].

The method proposed by the authors [6] consists in desilicating an aluminate solution using Friedel's salt $\left(\mathrm{Ca}_{2} \mathrm{Al}(\mathrm{OH})_{6} \mathrm{Cl} \cdot 2 \mathrm{H}_{2} \mathrm{O}\right)$. It has been shown that calcium chloride has higher desiliconizing properties. As an alternative, another author [11] proposed desiliconization of the solution to gypsum $\left(\mathrm{CaSO}_{4} \cdot 2 \mathrm{H}_{2} \mathrm{O}\right)$, which is cheaper and is found in large quantities. However, all the above-mentioned reagents as precipitators $\left(\mathrm{CaO}, \mathrm{Ca}(\mathrm{OH})_{2}\right.$ and calcium salts lead to additional costs in the desiliconization process.

In this work, the dynamics of the transition of silicon into solution during the leaching of raw Zaglik alunite ore in the alkaline solution is traced and the experimental results of the sorption of silica passed into the aluminate solution are investigated.

\section{Experimental part}

\section{Materials and methods}

The alunite ore raw materials used in the studies were taken from the Ganja Clay-soil Plant, and some samples of raw materials were taken directly from the deposit from the reservoir in accordance with the hardness and color of the rock. Samples were crushed and sifted through standard sieves, separated into certain fractions. Previously, it was determined that alunitized rock has a microcrystalline structure and individual silicon-containing minerals that make up the rock are too closely related to each other. The alunite mineral is also disseminated in loose rock (quartz) in separate pieces and connected to each other [4]. This fact allows the technologist to process alunite rocks by hydrochemical method without grinding.

The mass fraction of alunite in the selected rock samples varies in a wide range from $22.51 \%$ to $51 \%$. The results of chemical analysis of alunite rocks are shown in Table 1.

In Figure 1, a an X-ray diffraction pattern of alunite ores of the Zaglik deposit is shown. It has been established that the main mineral components of alunite ores are potassium-sodium alunite, kaolinite (dickite), hematite and quartz. According to X-ray diffraction data, aluminum in the ore is contained in alunite and dickite.

Table 1. Chemical analysis of alunite rock samples

\begin{tabular}{|c|c|c|c|c|c|c|c|c|c|}
\hline$\stackrel{0}{\sim}$ & \multicolumn{9}{|c|}{ Amount, \% } \\
\hline जี & $\mathrm{SiO}_{2}$ & $\mathrm{Al}_{2} \mathrm{O}_{3}$ & $\mathrm{Fe}_{2} \mathrm{O}_{3}$ & $\mathrm{SO}_{3}$ & $\mathrm{CaO}$ & $\mathrm{MgO}$ & $\begin{array}{c}\mathrm{Na}_{2} \mathrm{O}+ \\
\mathrm{K}_{2} \mathrm{O}\end{array}$ & $\mathrm{H}_{2} \mathrm{O}$ & \begin{tabular}{|l} 
Pure \\
alunit
\end{tabular} \\
\hline 1 & 41.4 & 21.7 & 5.05 & 20 & 0.2 & 0.12 & 5.1 & 6.5 & 50.2 \\
\hline 2 & 48.12 & 23.58 & 4.21 & 14.55 & 0.44 & 0.15 & 3.43 & 5.51 & 37 \\
\hline 3 & 31.09 & 24.09 & 4.14 & 27.11 & 0.13 & 0.11 & 6.88 & 5.4 & 51.0 \\
\hline 4 & 52.80 & 22.47 & 4.34 & 10.93 & 2.56 & 0.34 & 2.15 & \begin{tabular}{|l}
4.04 \\
\end{tabular} & 28.9 \\
\hline 5 & 50.12 & 28.99 & 2.52 & 10.83 & 2.96 & 0.66 & 2.60 & 1.31 & 28.7 \\
\hline 6 & 50.08 & 26.78 & 3.66 & 8.84 & 0.46 & 0.30 & 2.62 & \begin{tabular}{|l}
7.27 \\
\end{tabular} & 22.51 \\
\hline
\end{tabular}

In the process of leaching, the target mineral potassium alunite was extracted from the ore with a potassium hydroxide solution, while dickite, hematite and quartz remained in the leaching residue - alunite mud (Figure 1, b). The figures clearly show the diffraction lines characteristic of the indicated minerals.

The research technique consisted in

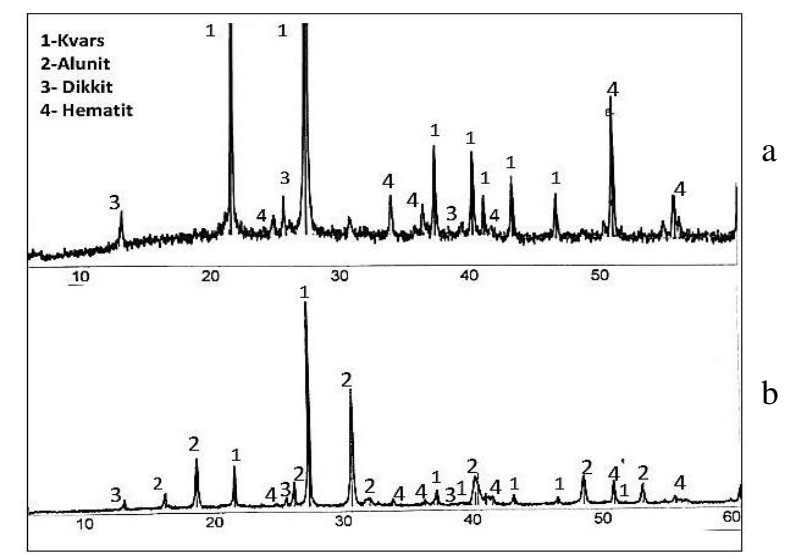

Fig. 1 X-ray diffraction patterns (a) of the raw alunite ore of the Zaglik deposit and (b) the residue after leaching.

mixing a sample of ore in a $\mathrm{KOH}$ solution so that in all cases an excess of alkali was provided. At the same time, an excess of alkali provides a high level of caustic modulus.

Since the alkaline solution is in contact with silicon dioxide, for the dynamics of its transition from alunite to the solution, it is not carried out in glass containers (plastic, porcelain containers), described in Figure 2. The vessels used in the experiments were made of a ma- 


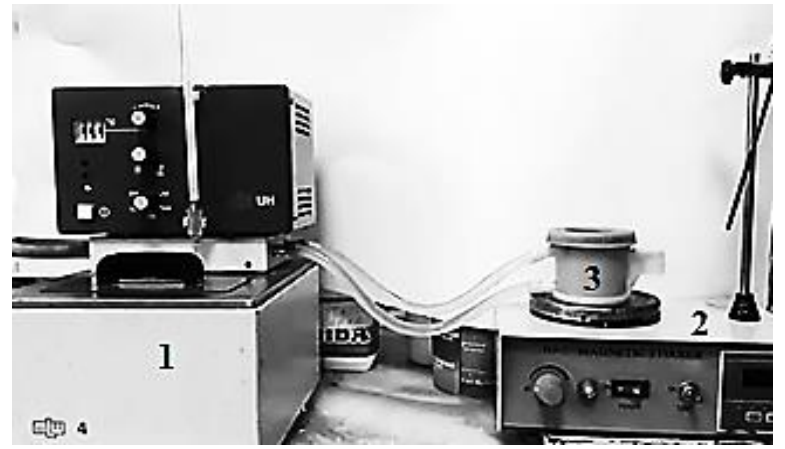

Fig. 2. Devise for dissolving alunite in an alkaline solution: 1) thermostat 2) magnetic stirrer, 3) container containing aluminate solution.

terial that renders inert to alkalis. The installlation, equipped with a thermostat and a magnetic stirrer, allows maintaining a constant temperature.

The concentration of silicate (IV) and aluminum in the filtrate was measured by an optical emission spectrometer with productively coupled plasma (8300 ICP-OES, Germany), and was also determined by the photocolorimetric method (FEK-3).

Sometimes the content of $\mathrm{SiO}_{2}, \mathrm{H}_{2} \mathrm{O}, \mathrm{SO}_{3}$ and $\mathrm{Al}_{2} \mathrm{O}_{3}$ in alunite and its processing products was determined by the gravimetric method, $\mathrm{Fe}_{2} \mathrm{O}_{3}$-iodometric, $\mathrm{K}_{2} \mathrm{O}$ and $\mathrm{Na}_{2} \mathrm{O}$ - flame photometric methods.

\section{Results and discussions}

As can be seen from Table 1, the $\mathrm{SiO}_{2}$ content in alunite ranges from 31.09 to $52.8 \%$. Silicon is distributed in the form of amorphous quartz, kaolinite (dickite) and chlorite in Zaglik alunite. The presence of $\mathrm{SiO}_{2}$ in the ore in the crystal structure of quartz facilitates its processing with alkaline solutions. Thus, quartz is practically insoluble in alkaline and aluminate solutions at low temperatures $\left(<100^{\circ} \mathrm{C}\right)$. When reacting with an alkaline solution, only active (amorphous) silicon reacts. According to researchers, the source of contamination of aluminate solutions is active silicon dioxide and silicon in kaolinite [2, 4].

Studies have shown that alunitized rock decomposes with alkali solutions as easily as a pure mineral [4]. We studied the kinetic regularities of the leaching of alunite ore in alkaline solutions in [12]. Alunite ore is treated with the alkaline solution at a temperature of $95-98^{0} \mathrm{C}$ and leached within 30 minutes. At the same time, alumina (in the form of aluminate) and alkali metal sulfates (potassium and sodium) pass into the solution

$$
\begin{aligned}
& \mathrm{KAl}_{3}(\mathrm{OH})_{6}\left(\mathrm{SO}_{4}\right)_{2}+6 \mathrm{KOH}=2 \mathrm{~K}_{2} \mathrm{SO}_{4}+3 \mathrm{KAlO}_{2}+6 \mathrm{H}_{2} \mathrm{O} \\
& 2 \mathrm{KAl}_{3}(\mathrm{OH})_{6}\left(\mathrm{SO}_{4}\right)_{2}+2 \mathrm{NaOH}=6 \mathrm{NaAlO}_{2}+3 \mathrm{Na}_{2} \mathrm{SO}_{4}+ \\
& +\mathrm{K}_{2} \mathrm{SO}_{4}+12 \mathrm{H}_{2} \mathrm{O}
\end{aligned}
$$

Quartz is practically insoluble under these conditions. If alunitized rock is contaminated with active forms (opal, chalcedony) of silica, it easily goes into solution during alkaline leaching. The efficiency of processing alunitized rock by this method is greatly reduced. Waste (alunite mud) is separated by sedimentation and goes to the dump. The resulting clarified aluminate solution is desilicated in open mixers at a temperature of $103-105^{\circ} \mathrm{C}$. At the factory, to speed up the desiliconization process, white mud is added to the solution in the form of seeds in an amount of $100 \mathrm{~g} / \mathrm{l}$ from the previous desiliconization operation. The desiliconization of aluminate solutions with white mud is complete, and already in the first two hours of desiliconization of the silica modulus in the solution is about 300 [2].

With alkaline leaching of roasted alunite at an alumina plant, the concentration of $\mathrm{SiO}_{2}$ in the solution reaches $200-300 \mathrm{mg} / \mathrm{l}$ [4]. If active forms of silica are present in samples, this figure is sometimes reached up to $0.8-1 \mathrm{~g} / \mathrm{l}$. Since our proposed new technology for processing alunite does not consider the process of its roasting, it would be cost-effective to study the transition of $\mathrm{SiO}_{2}$ into solution during leaching of the raw material.

Studies with alunite ore have shown that of the four basic minerals (alunite, dickite, quartz and hematite), alunite easily and quickly dissolves in alkaline solutions $(\mathrm{NaOH}, \mathrm{KOH})$ [13].

The transition of silicon into solution during leaching with alkali was tested on raw alunite ore. The results are shown in Figure 3.

As can be seen from Figure 3, the transition of silicon into solution up to $40^{\circ} \mathrm{C}$ in 1 hour is insignificant $(1 \mathrm{mg} / \mathrm{l})$. Starting from $50^{\circ} \mathrm{C}$, the transition of silicon into solution is accelerated $(2.5 \mathrm{mg} / \mathrm{l})$, at a temperature of $70^{\circ} \mathrm{C}$, 
the concentration of silicon dioxide in the solution is $25 \mathrm{mg} / \mathrm{l}$. This indicator is very low in comparison with silicon dioxide, which goes into solution upon alkaline leaching of roasted alunite. An increase in the contact time to 3 hours leads to an increase in the $\mathrm{SiO}_{2}$ concentration in the solution by a factor of $3(42.8$ $\mathrm{mg} / \mathrm{l})$. As can be seen from the graph, temperature and time affect the release of silicon dioxide into solution.

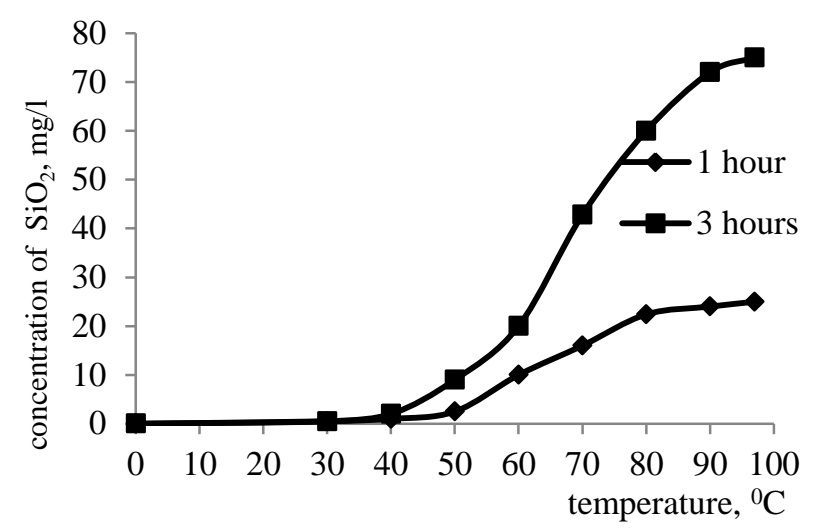

Fig. 3. Temperature dependence on the concentration of silicon dioxide in solution at different points in time during leaching of raw alunite in alkali $\left(\mathrm{m}_{\mathrm{al}}=10\right.$ $\mathrm{g}, \mathrm{C}_{\mathrm{NaOH}}=5 \%, \mathrm{~S}: \mathrm{L}=1: 5$ ).

For comparison, the experiments were carried out with a sample of roasted alunite $\left(620^{\circ} \mathrm{C}\right)$. The concentration of $\mathrm{SiO}_{2}$ dissolved in $10 \%$ alkali at a temperature of $90^{\circ} \mathrm{C}$ was 390 $\mathrm{mg} / \mathrm{l}$. This indicates that when alunite is fired at room temperature, the crystal lattice of the kaolinite mineral in it is destroyed, and the number of components in the solution increases.

With alkaline leaching of roasted alunite at the alumina plant, the amount of $\mathrm{SiO}_{2}$ in the solution reaches $200-300 \mathrm{mg} / \mathrm{l}$ [4]. For comparison: the concentration of $\mathrm{SiO}_{2}$ released during alkaline leaching of roasted alunite is $4-5$ times higher than the solubility of wet alunite under the same conditions.

As a result of the research, the aluminate solution of the following composition was obtained: $52.3 \mathrm{~g} / \mathrm{l} \mathrm{NaOH}, 40.8 \mathrm{~g} / 1 \mathrm{Al}_{2} \mathrm{O}_{3}, 1.85 \mathrm{~g} / \mathrm{l}$ $\mathrm{KOH}, 1 \mathrm{~g} / 1 \mathrm{SO}_{2}, 0.39 \mathrm{~g} / 1 \mathrm{SiO}_{2}$.

Studies have shown that the main disadvantage of the process is the high silicon content in the solution after filtration $(0.39 \mathrm{~g} / \mathrm{l})$ and the low concentration of $\mathrm{Al}_{2} \mathrm{O}_{3}(40.8 \mathrm{~g} / \mathrm{l})$. The- refore, further research focused on decreasing the silicon concentration and increasing the $\mathrm{Al}_{2} \mathrm{O}_{3}$ concentration. For this, the pulp was recirculated and the process conditions were maintained as at the initial stage.

The circulation results are shown in Table 2.

Table 2. Concentration of elements in solution during repeating the cycle

\begin{tabular}{|c|c|c|c|c|c|}
\hline & $\mathrm{Al}, \mathrm{g} / \mathrm{l}$ & $\mathrm{Si}, \mathrm{g} / \mathrm{l}$ & $\mathrm{K}, \mathrm{g} / \mathrm{l}$ & $\mathrm{Na}, \mathrm{g} / \mathrm{l}$ & $\mathrm{S}, \mathrm{g} / \mathrm{l}$ \\
\hline 1 & 40.8 & 0.39 & 1.85 & 52.3 & 1.0 \\
\hline 2 & 41.5 & 0.3 & 3.00 & 52.0 & 2.02 \\
\hline 3 & 50.0 & 0.17 & 3.90 & 49.1 & 2.98 \\
\hline 4 & 59.6 & 0.08 & 4.60 & 46.7 & 4.40 \\
\hline 5 & 68.0 & 0.05 & 5.01 & 44.6 & 5.80 \\
\hline 6 & 68.7 & 0.01 & 5.49 & 43.6 & 6.10 \\
\hline 7 & 69.2 & 0.003 & 6.00 & 43.2 & 6.40 \\
\hline 8 & 69.7 & 0 & 6.45 & 42.9 & 6.80 \\
\hline 9 & 70.3 & 0 & 6.60 & 42.8 & 7.00 \\
\hline 10 & 71.2 & 0 & 6.80 & 42.5 & 7.20 \\
\hline
\end{tabular}

As you can see from the data Table 2, during the recirculation of the aluminate solution, the concentration of aluminum is observed, while desiliconization sharply increases. Thus, after sevenfold circulation, the aluminum concentration increases by almost 1.7 times, while silicon is only traced $(0.003 \mathrm{~g} / \mathrm{l})$ and in subsequent cycles the solution is completely desilicated. This behavior of silicon in circulation processes is probably explained by the fact that when leaching alunite, the resulting mud has sorption properties. To confirm this version, a sample of alunite mud was dried (in the range of $\left.100-110^{\circ} \mathrm{C}\right)$, sulfatized and subjected to $\mathrm{X}$ ray phase analysis (Figure 4 ). The diffractogram shows the presence of $\mathrm{SiO}_{2}, \mathrm{Fe}_{2} \mathrm{O}_{3}$, hydrocalumite $\mathrm{Ca}_{6} \mathrm{Al}(\mathrm{OH})_{18}\left(\mathrm{SO}_{4}\right)_{1.5}\left(\mathrm{H}_{2} \mathrm{O}\right)_{9}$ and other phases. In works [14, 15] it was proved that hematite $(\mathrm{FeOOH})$, goethite $\left(\mathrm{Fe}_{2} \mathrm{O}_{3}\right)$ and hydrocalumite $\left(\mathrm{Ca}_{6} \mathrm{Al}(\mathrm{OH})_{18}\left(\mathrm{SO}_{4}\right)_{1.5}\left(\mathrm{H}_{2} \mathrm{O}\right)_{9}\right)$ has adsorption properties in relation to silicate ions, which leads to desiliconization of the aluminate solution. In the process of circulating the aluminate solution, the concentration of potassium ions increases significantly from $1.86 \mathrm{~g} / \mathrm{l}$ to $6.8 \mathrm{~g} / \mathrm{l}$.

Since the remainder of alunite does not contain valuable components, the use of any technological process on its basis will always lead to unprofitable results. Information on the use of compounds contained in these wastes as 
an active component for the adsorption of anionic pollutants is highlighted in the literature $[16,17]$. The preparation of adsorbents on the basis of alunite residue, along with the cleaning of the worked solutions from anions, also makes it possible to control the level of pollution and turn it into an eco-friendly product. To obtain a pure aluminate solution, we studied the purification of silicon from an alkaline solution by adsorption with an activated mud.

Activation of alunite mud: $10 \mathrm{~g}$ of dried mud powder was placed in a porcelain bowl, then $6 \mathrm{ml}$ of concentrated sulfuric acid $(\rho=1.84$ $\mathrm{g} / \mathrm{cm}^{3}$ ) was added. The resulting mixture was dried in an oven at $130^{\circ} \mathrm{C}$ for 12 hours. The dried mass was subjected to heat treatment in a muffle furnace at various temperatures $\left(400-600^{\circ} \mathrm{C}\right)$. XRD analysis of conventional and activated mud showed that the sulfate phase of hydrocalumite $\left(\mathrm{Ca}_{6} \mathrm{Al}(\mathrm{OH})_{18}\left(\mathrm{SO}_{4}\right)_{1.5}\left(\mathrm{H}_{2} \mathrm{O}\right)_{9}\right)$ was formed in the activated alunite residue (Figure 4).

The literature shows that the chloride form of this compound is effective for the adsorption of $\mathrm{SiO}_{2}$ [14].

Experiments have shown that mud activated with sulfuric acid has the ability to release silicate ion from aluminate solutions with a high yield compared to untreated mud. The results of these experiments are shown in Figure 5.

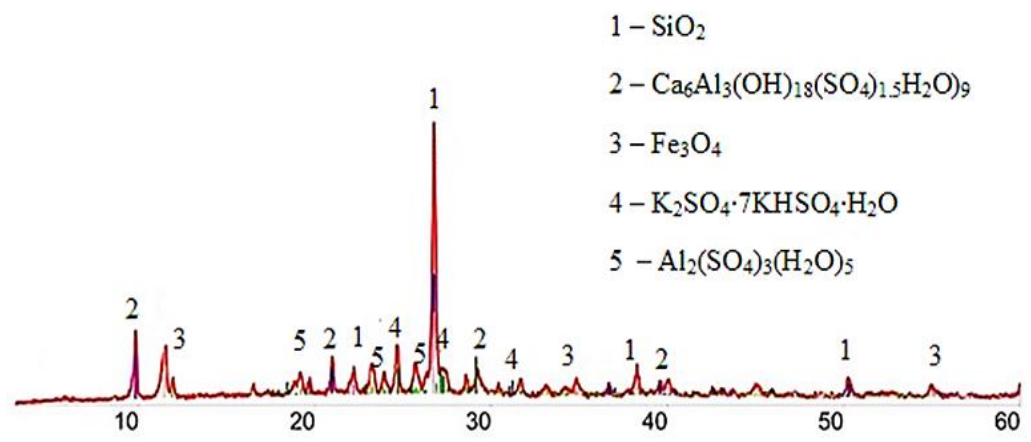

Fig. 4. X-ray phase analysis of the residue of sulfated alunite mud.

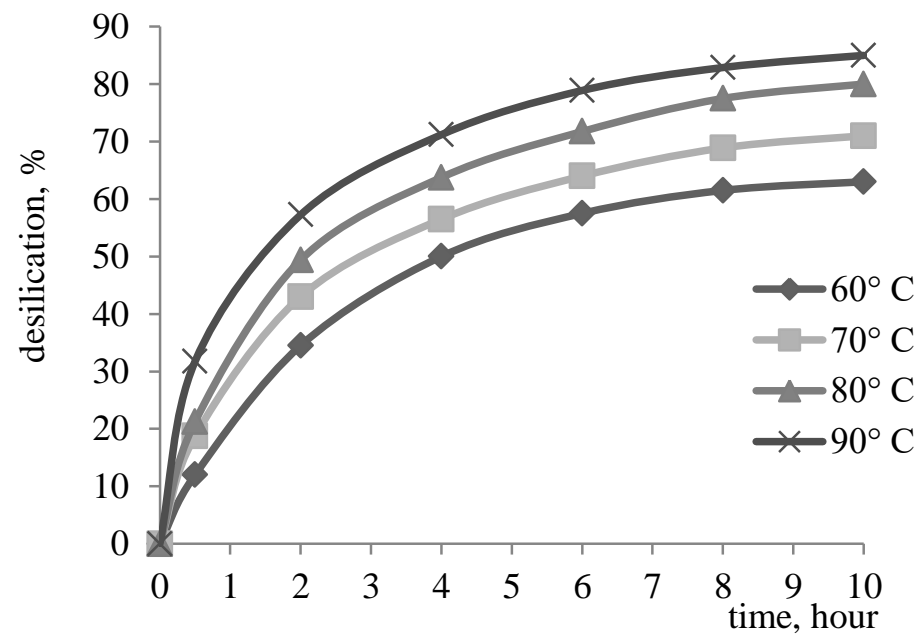

Fig. 5. Dependence of desilication on time at different temperatures $\left(C_{0}=0.2 \mathrm{~g} / \mathrm{l}, \mathrm{S}: \mathrm{L}=1: 5\right)$. 
Figure 5 shows the percentage of adsorption of silicate ion in solution on an activated alunite residue as a function of time and temperature. As you can see, desiliconization occurs rather quickly (within 3 hours). An increase in temperature increases the rate of desilication of silicon in solution. At different temperatures, the concentration of $\mathrm{SiO}_{2}$ in comparison with the initial concentration decreases rapidly, and with a further increase in time, the rate of desiliconization does not change noticeably.

Within 10 hours at a temperature of $90^{\circ} \mathrm{C}$, the separation of $\mathrm{SiO}_{2}$ from the aluminate solution by $85 \%$ is achieved.

\section{References}

1. Kashkay M.A. Alunity ikh genezis i ispol'zovaniye. M.: Nedra, 1970. T. 1.318 c.

2. Labutin G.V. Alunity. M.: Metallurgiya, 1965. 98 s.

3. Addai Mensah J. Jones R, Zbik M., Gerson A.R. Sodium aluminosilicate scale formation on steel substrates: Experimental design and assessment of fouling behaviour. Light Metals. 2003. P. 25-34.

4. Tagiyev E.I. Tekhnologiya kompleksnoy bezotkhodnoy pererabotki alunitovoy rud. Baku: Elm, 2006. $504 \mathrm{~s}$.

5. Noworyta A. On the removal of silica from aluminate solutions: Mechanism and kinetics of the process. Hydrometallurgy. 1981. V. 7. № 1-2. P. 99-106.

6. Maa J., Lia Z., Zhang Y., Demopoulos G.P. Desilication of sodium aluminate solution by Friedel's salt (FS: $3 \mathrm{CaO} \cdot \mathrm{Al}_{2} \mathrm{O}_{3} \cdot \mathrm{CaCl}_{2} \cdot 10 \mathrm{H}_{2} \mathrm{O}$ ). Hydrometallurgy. 2009. V. 99. № 3-4. P. 225-230.

7. Zhao H., Hu H., Jinn M., Li J., Li Q., Liu Y. Digestion of diasporic bauxite with mass ratio of $\mathrm{Al}_{2} \mathrm{O}_{3} / \mathrm{SiO}_{2} \mathrm{NO}$ greater than 7 by Bayer process with an excessive addition of lime. Light metals. TMS. Warrendale. 2002. P. 101-104.

8. Gu S., Yin Z., Qi L. Intensifying method of Bayer digestion process of diasporic bauxite in China. Light metals. TMS. Warrendale. 2002. P. 83-88.

9. Pat. 4455284 US. Process of desilication of aluminate solution. Sizyakov V.M., Kaluzkhky N.A., Badiants K.A. 1984.

10. Yuan J., Zhang Y. Desiliconization reaction of sodium aluminate by adding tricalcium hidroaluminate. Hydrometallurgy. 2009. V. 195. P. 166-169.

11. Li Y.G., Wang Y., Zhai Y. Deep desiliconization of mid-high aluminate concentration solution with calcium sulfate. The Chinese Journal of Process Engineering. 2008. V. 8. № 2. P. 253-257.

12. Geidarov A.A., Alyshanly G.I., Gulieva A.A., Tagieva L.T., Alieva V.A. Kinetic laws of the dissolution of alunite from alunite ores with an alkali solution. Russian Metallurgy (Metally). 2020.№ 9. P. 933-937.

13. Kashkay Ch.M., Gaydarov A.A., Kerimov R.B., Agayev A.N., Jafarov Z.R.. Alunite technology based on heap leaching. Azerb. Chem. J. 2017. № 1. P. 77-79.

14. Nguyen T.N., Lee M.S. The removal of silicate (IV) by adsorbtion onto hydrocalumite from the sodium hydroxide leaching solution of black dross. Processes. 2019. V. 7. № 6. P. 612-624.

15. Ruan S., Shi L., Li J., Gerson A.R. Desilication of hematite, goethite and iron powder seeded low alumina to caustic liquors. Hydrometallurgy. 2017. V. 169. P. 297-305.

16. Altundoğan H.C., Altundoğan S., Tümen F., Bildik M. Arsenic adsorption from aqueous solutions by activated red mud. Waste Managment. 2002. V. 22. P. 357-363.

17. Li Y., Liu C., Luan Z., Peng X., Zhu C., Chen Z., Zhang Z., Fan J., Jia Z. Phospate removal from aqueous solutions using raw and activated red mud and fly ash. J. Hazardous Material B 137. 2006. P. 374-383.

\title{
XAM ALUNITIN QəLӘVIDə HəLLOLMASINDAN ALINAN ALÜMINATLI MOHLULLARA SILISIUMUN KEÇMəSI Və ONUN MəHLULDAN ÇIXARILMASI ŞəRAİTININ TəDQİQI
}

\begin{abstract}
G.İ.Alıșanlı
Alüminiumu Zəylik alunit filizindən qələvi həlletmə yolu ilə çıxaran zaman alunitin tərkibindəki silisium silikat ionu şəkilində az da olsa məhlula keçir. Məhluldakı silisium alınan gil torpağın keyfiyyətinə təsir etməklə yanaşı, istehsalat zamanı boru və avadanlıqların ərplə dolmasına səbəb olur. Təqdim olunan bu məqalədə xam alunitin otaq temperaturunda və qızdırmaqla qələvi məhlulunda həllolması zamanı silisiumun maye fazada paylanma dinamikası izlənmişdir. Yüksək keyfiyyətli alüminium hidroksid almaq üçün silisiumun alüminat məhlulundan çıxarılması metodu təklif olunur. Silisiumsuzlaşdırma ana məhlulun təkrarən dövrəyə qaytarılması ilə aparılmışdır. Bu metoda görə alunit şlamının aktivləşdirilməsi nəticəsində əldə edilən materialın məhluldan silisium (IV) oksidi sorbsiya etmə qabiliyyəti araşdırılmışdır. Tapıldı ki, sulfat turşusu ilə aktivləşdirilmiş alunit şlamı emal edilməmiş alunit şlamına nisbətən silikat ionunu alüminat məhlullarından yüksək çıxım faizi ilə ayırma qabiliyyətinə malikdir.
\end{abstract}

Açar sözlor: alunit, silisiumsuzlaşdırma, qələvi, hidrokalumit, Friedel duzu. 


\section{ИССЛЕДОВАНИЕ УСЛОВИЙ ПЕРЕХОДА КРЕМНИЯ В АЛЮМИНАТНЫЙ РАСТВОР ПРИ ВЫЩЕЛАЧИВАНИИ СЫРОГО АЛУНИТА И ЕГО УДАЛЕНИЕ ИЗ ЭТОГО РАСТВОРА}

\section{Г.И.Алышанлы}

При экстракции алюминия из алунитовой руды Загликского месторождения путем выщелачивания кремний, входящий в состав алунита, переходит в раствор в виде силикатного иона в небольшом количестве. Кремний в растворе не только ухудшает качество полученного глинозема, но также способствует засорению труб и оборудования во время его производства. В данной работе исследована динамика распределения кремния в жидкой фазе при растворении сырого алунита при комнатной температуре и нагревании в щелочном растворе. Предложен метод извлечения кремния из алюминатного раствора для получения гидроксида алюминия высокого качества. Обескремнивание проводили путем рециркуляции исходного раствора. Исследована способность сорбции диоксид кремния из раствора, полученного в результате кислотной активации алунитового шлама. Установлено, что активированный серной кислотой алунитовый шлам в сравнении с неактивированным обладает способностью отделять силикатный ион от алюминатного раствора с более высоким процентом выхода.

Ключевые слова: алунит, обескремнивания, щелочь, гидрокалумит, соль Фриделя. 